\title{
DESCRIPTION OF THE LABOUR MARKET STATUS OF YOUNG PEOPLE IN SELECTED COUNTRIES OF THE EUROPEAN UNION - THE TAXONOMIC APPROACH
}

\section{Grażyna Trzpiot}

University of Economics in Katowice, Katowice, Poland e-mail: grazyna.trzpiot@ue.katowice.pl

ORCID: 0000-0002-5129-5764

\section{Magdalena Kawecka}

University of Economics in Katowice, Katowice, Poland e-mail: magdalena.kawecka@edu.uekat.pl

ORCID: 0000-0001-7671-8340

\section{(C) 2021 Grażyna Trzpiot, Magdalena Kawecka}

This work is licensed under the Creative Commons Attribution-ShareAlike 4.0 International License. To view a copy of this license, visit http://creativecommons.org/licenses/by-sa/4.0/

Quote as: Trzpiot, G., and Kawecka, M. (2021). Description of the labour market status of young people in selected countries of the European Union - the taxonomic approach. Econometrics. Ekonometria. Advances in Applied Data Analysis, 25(4).

DOI: 10.15611/eada.2021.4.02

JEL Classification: C38, J24, F16

\begin{abstract}
The primary objective of the article was to classify objects that are labour markets of young people in selected EU countries in order to create relatively homogeneous groups based on the set of variables considered. This allowed to examine the similarities of the selected member states and to compare the two years of 2008 and 2018. The analysis used EUROSTAT (17 macroeconomic and demographic variables) data for selected EU countries. The study used hierarchical methods to agglomerate objects through a dendrogram to illustrate the linkages between countries applying Ward's method for Euclidean distances. A non-hierarchical $k$-means method was also used to examine the allocation of objects and assess the relevance of the study by minimizing the variability within the resulting clusters, thereby maximizing the variability between them. The results provide a basis for improving the measurement of the situation of young people in the labour market by showing factors significantly influencing the level of employment and unemployment of young people. This study opens the door to future research on the labour market situation in the member states.
\end{abstract}

Keywords: labour market, cluster analysis, taxonomic approach, European Union countries. 


\section{Introduction}

The national economies of the EU member states are the subject of many comparative studies. Naturally, the labour market is a very important segment of each country's economy. Research of this type amounts to identifying differences between countries or identifying existing similarities. The multidimensionality of the national economies of the selected countries made it possible to use variables which directly describe the labour market situation of young people in selected European Union countries. As defined by Dagnelie (1975): "multidimensional statistical analysis should be treated as a set of statistical methods which aim to examine the relationships existing between multiple dependent or interdepending variables". Thus, multidimensional analysis focuses on multiple variables that apply to the same objects or phenomena and the variables studied are dependent or interdependent (Balicki, 2013).

The scope of the paper covers selected variables characterising the labour markets of six EU member states. Based on substantive and formal-statistical criteria (such as universality, variability, degree of correlation, validity), 17 macroeconomic and demographic variables representing the supply and demand labour market situation in selected European countries in 2008 and 2018 were selected for the study. In addition to the substantive criterion, account was also taken of the availability, comparability and timeliness of the statistics. The grouping of the selected units contained in multi-dimensional variable spaces can be carried out with different research methods, so a cluster analysis was used to determine the similarities and differences between these countries (Cormack, 1971; Mardia, Kent, \& Bibby, 1979; Marek, 1989). The classification of the countries was carried out using the Ward method - an example of hierarchical methods and the $k$-means grouping method - as an example of non-hierarchical methods (Aczel, 2017; MacQueen, 1967).

The analysis of the situation of young people in the selected EU countries encouraged the authors to contribute to this discussion, which not only indicates data clusters of similar countries, but above all focuses on the narrow group of young people aged 20-24 beginning their adventure on the labour market. Research to date has focused on the study of young people in a certain generalisation, using age groups such as: up to 25 years of age; $15-24 ; 15-34 ; 25-29 ; 30-34$ and others. In the literature, these are the social groups most frequently addressed, which is a justified choice by researchers. The study has made it possible to show the situation of a narrow group of young people who belong to the groups of unemployed, employed, but also studying. By singling out six countries, the study demonstrates the global problem of unemployment, which is influenced by factors directly linked to the group in question.

The main aim of the paper was to identify statistically significant variables that describe the similarities between the labour markets of young people aged 20-24 in the selected EU countries. The study aimed to identify similarities and differences in 
the youth labour market between individual countries, and to group them. The operationalisation of variables for this purpose seeks to group the test diagnostic characteristics together to form homogeneous groups that take into account their internal differentiation using hierarchical and non-hierarchical methods of cluster analysis (Frątczak, 2009; Hartigan \& Wong, 1978; Mikulec, 2013).

The research hypothesis is that the chosen studied diagnostic characteristics of youth labour markets in selected EU countries are an extremely important criterion of belonging to a given group, which directly and indirectly affect the employment of young people. An important research question is which EU member states, due to macroeconomic and demographic factors, are similar to each other in terms of the labour market situation of young people in the given years. The article also answers the questions: "Which EU countries form clusters and what variables determine these clusters?", as well as "How has the labour market situation of young people changed over the decade?".

The following countries in the Central-Western Europe were included in the study: Austria, the Czech Republic, France, Germany, Poland and Hungary. The introduction of regional divisions based on geographical foundations after 1989 made it possible to study new geopolitical, cultural and economic relationships (Laczó \& Gabrijelčič, 2020). The authors of the essays in a collective publication entitled "The Legacy of Division. East and West after 1989", edited by F. Laczó and L.L. Gabrijelčič, noted that the accession of the Central and Eastern European countries to the EU has had a significant impact on regional divisions, thus showing that Eastern Europe (Russia, Ukraine, Moldova and other countries in the region) is different from Western and Central European countries. Zielonka (in Laczó \& Gabrijelčič, 2020, pp. 70-76) stated that Central and Eastern European countries have more in common with Western countries than with Eastern countries and other regions. The rationale for choosing the EU countries for the study was the aforementioned division, but above all, the accession of the countries to the EU, which allowed for their dynamic development in economic, as well as geopolitical and cultural terms. Moreover, the selected countries allowed for the identification of similarities between the countries of Western and Central Europe. The data covered two years - 2008 and 2018 - and focused on a group of young people aged 20-24. The comparison of the two periods over a decade made it possible to observe the changes in terms of the level of unemployment and the factors characterising the groups formed. This study also indicated which taxonomic method is more accurate in terms of studying unemployment. The source of the data was Eurostat.

The first chapter is an introduction to the topic of the article. It discusses the research gap, the research objective, the research hypothesis, as well as the research problem and the questions the article answers. The second chapter focuses on the literature review of the subject under study. The third chapter presents the research methods and procedures, namely the theories in the field of cluster analysis. The fourth chapter presents the research results with relevant interpretations for 2008 and 
2018. The fifth chapter undertakes a discussion of the research and the cluster analysis research results. The last chapter is a summary of the whole article, and contains the most important conclusions about the studied phenomenon.

\section{Literature review}

In the literature on the subject, the labour market is described as an area of extraordinary dynamics of change understood as a certain process around which economic transactions occur (Lichtarski, 1999). He suggested that perceiving it from the perspective of economic sciences, one say that it is one of the areas of activities which, according to the essence of economics, deals with a purchase-sale transaction, and the object of this transaction is labour. This is an economic process which regulates and drives the volume of labour supply (the potential offered by persons (candidates) looking for work) and labour demand (i.e. the potential expressed by employers in terms of the amount of labour necessary for the functioning of their enterprise/organisation). This means that, on the one hand, there is a person who is actively looking for a job (expresses willingness to be employed), while on the other a person who is looking for someone who will do the job. One of these groups comprises young people who face numerous limitations on the labour market, related in particular to their lack of professional experience and qualifications, as observed by Osiecka-Chojnacka (2007). Stasiak (2011) also mentioned the participation in education of young people, as well as social integration, which sometimes play a key role in the decision on active job search. The Act of 20 April 2004 on employment promotion and labour market institutions speaks about the state's task "in the field of employment promotion, mitigating the results of unemployment and professional activation", which through its activities aims at "full and productive employment; develop human resources; achieve high quality of work and strengthen and integration and social solidarity" (Nojszewska, 1995). The economically active population in economic theory is understood to be people of working age who are able and willing to work (referred to as the labour force). This group includes both those who are working (employed) and those who are not working (unemployed). The economically active population includes all those who are working and therefore employed as well as the unemployed (people of working age who are unemployed and ready to work) (Milewski, 2017).

The entry of young people into the labour market is mainly linked with the difficulties they encounter on the labour market. This was noted by a few researchers (Krause, 2016; Rybicka, 2014; Saczyńska-Sokół \& Łojko, 2016; Szcześniak \& Rondón, 2011), who listed a number of factors that contribute to increased unemployment among young people. They referred to individual factors related to, among others, educational attainment, social integration (lower sense of worth due to material deprivation, poverty and social exclusion), low social competences, and negative (passive) attitudes towards job search. The authors noted that all these 
factors induce a reluctance among young people, and in the case of taking up employment, a lack of satisfaction from it, low motivation, and thus a pessimistic attitude to self-development and developing own competences in order to improve qualifications. Rachwał (2005) observed that such an attitude is in total contrast to the widely understood economic-entrepreneurial attitude, which in the economy (and thus in the labour market) is treated as a key competence for taking up employment (Kompetencje..., 2007).

Other studies (Bauman, Bauman, Kociatkiewicz, \& Kostera, 2017) observed that there is a natural change in the labour market and the role of human capital through the dynamic development of the environment, the evolution of enterprise/ organization structures, as well as the architecture and functions of management. The EU labour market is entering a state of dynamic changes of qualitative and quantitative nature. Researchers noted that the working-age population (able to work) is decreasing and is projected to fall from over 300 million to 280 million in 2030 (Drela, 2017; Feifs, 2011), whereas some studies (Lewandowski \& Rutkowski, 2017; Jamka, 2009) found an increasing trend of people aged over 60 . These phenomena have a negative impact on the structure of the EU, as well as local and regional labour markets. In the context of the contemporary market and the emerging barriers to the activation of young people in the last two decades in both the Polish and European markets, Jadamus-Hacura \& Melich-Iwanek (2015) pointed out that the factor that most determines the contemporary labour market is the use of the increasing capacity for flexibility and, consequently, expanding the knowledge and mobility of young people in the new economy.

The labour market is a subject of interest in many economic sciences and social sciences in the broader world. The situation on the labour market of young people aged 20-24 in selected countries of the European Union is determined by a number of factors. The labour market between 2008 and 2018 was subject to a number of significant changes with both positive and negative effects.

The socio-demographic assessment of the labour market allowed for a clearer understanding of the structure of young people aged 20-24 compared to selected EU countries, which in future studies will allow for a broader understanding of the level of employment and youth unemployment.

The population of young people aged 20-24 between 2009 and 2018 represents the number of inhabitants of a given country on 1 January of a given year ${ }^{1}$.

${ }^{1}$ Population "is the «habitually resident population» and means all persons who are resident in a member state at the time of reference. According to that concept, the following persons are usually considered to be residents of a given geographical area: persons who have lived continuously in their place of residence for at least 12 months before the reference date or persons who arrived at their habitual residence within 12 months before the reference date with the intention of staying there for at least one year. If the circumstances described above cannot be established, «habitual residence» may be understood as the place of legal or registered residence" (Eurostat (b), n.d.). 


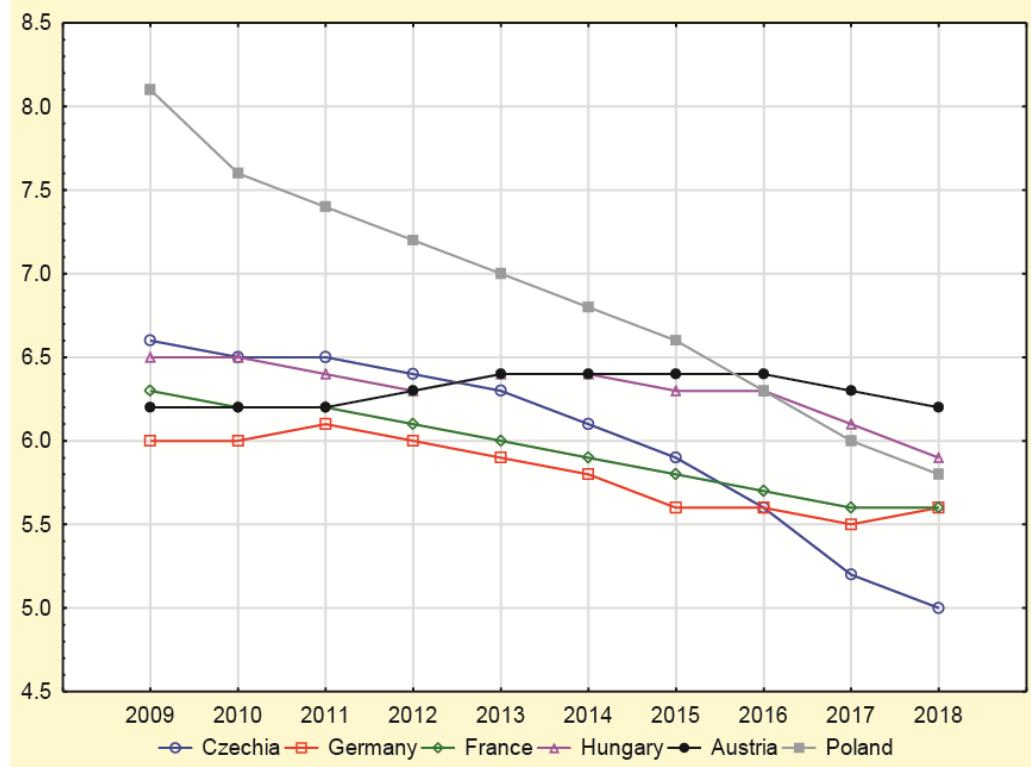

Fig. 1. Ratio of children and young people aged 20-24 in the total population on 1 January by sex and age in selected EU countries in 2009-2018 [in \%]

Source: own elaboration based on (Eurostat (a), n.d.).

Figure 1 shows the ratio of children and young people aged 20-24 in the total population on 1 January by sex and age in selected EU countries in percentages in $2009-2018^{2}$. Due to the lack of available data for 2008, the chart presents data for the years 2009 to 2018. As can be seen, Poland stands out in comparison to other countries in terms of the selected member states. The share of young people in the total population in 2009 was $8.1 \%$, while in $20185.5 \%$ (a decrease of $2.6 \%$ ). The next country was Czechia with $6.6 \%$ share of young people in the total population; in 2018 there was a decrease of $1.9 \%$. The other countries in 2009 were: Hungary (6.5\%), France $(6.3 \%)$, Austria (6.2\%) and Germany $(6 \%)$, where a decrease can be observed of less than $1 \%$, i.e. Hungary (0.8), France (0.7), Austria (0.2) and Germany (0.5). As can be seen in the selected member states, a decline in the population of young people aged 20-24 as a proportion of the total population was evident between 2009 and 2018. However, one of the reasons for this change is the increase in life expectancy with a decrease in the birth rate and therefore

${ }^{2}$ Eurostat aims at collecting from the EU member states data on population on 1 January every year. The recommended definition is the 'habitually resident population' and represents the number of inhabitants of a given area on 1 January of the year in question (or, in some cases, on 31st December of the previous year). However, the population reported by the countries can also be either based on data from the most recent census adjusted by the components of population change produced since the last census, or based on population registers (Eurostat (b), n.d.). 
a continuous increase in the elderly population as a proportion of the total population. Among these determinants, three factors can be mentioned: "the past as well as the current trends in fertility and mortality, and migration movements" (Janiszewska \& Dmochowska-Dudek, 2017). In addition, an important factor influencing the decline in the number of young people is the change in people's awareness in terms of selfdevelopment and thus achieving material benefits through active professional development. The preference for the number of children has also changed, while in the past having a large family was natural. This situation began to change at the end of the 19th century when the costs associated with having more children were too great for working parents to manage (Friedman, 2010). The author also noted that children ceased to be a factor multiplying wealth, but a kind of 'luxury good' that only well-off and financially stable families could afford. It should be mentioned that nowadays, states try to encourage procreation in order to increase the number of births through social programmes, and education. Figure 1 shows that the proportion of young people in the total population in selected countries ranges from $4.7 \%$ to $6 \%$, as confirmed by the maps below (Figure 2).
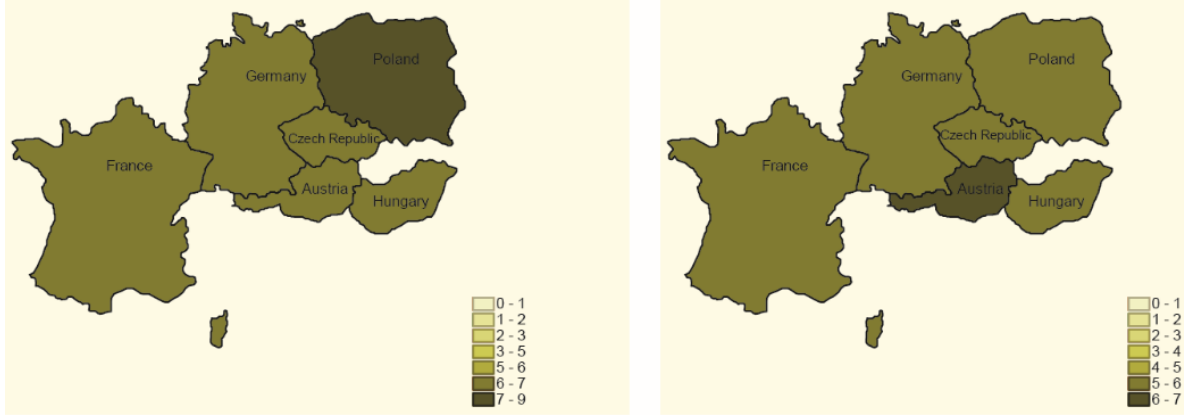

Fig. 2. Ratio of children and young people aged 20-24 in the total population on 1 January by sex and age in the selected European Union countries [in \%]

Source: own elaboration based on (Eurostat (a), n.d.).

After analysing the EU population, Austria and Hungary showed the highest ratio of children and young aged 20-24 people in the total population in 2018. In contrast, the other countries: the Czech Republic, Germany, Poland and France, it is slightly lower.

The unemployment rate (Figure 3) of young people, as one can see, is constantly changing - the highest rate during the decade was recorded in 2012 in Hungary at $26.4 \%$, where after 6 years it decreased to $8.6 \%$ (i.e. even by $67 \%$, while compared to 2008 by $51 \%$ ). Decreases in the unemployment rate in 2018 compared to 2008 can also be observed in Germany (by 45\%), Poland (by 34\%) and the Czech Republic 
(by 30\%). An increase in the unemployment rate was recorded in Austria (by 25\%) and France (by 15\%).

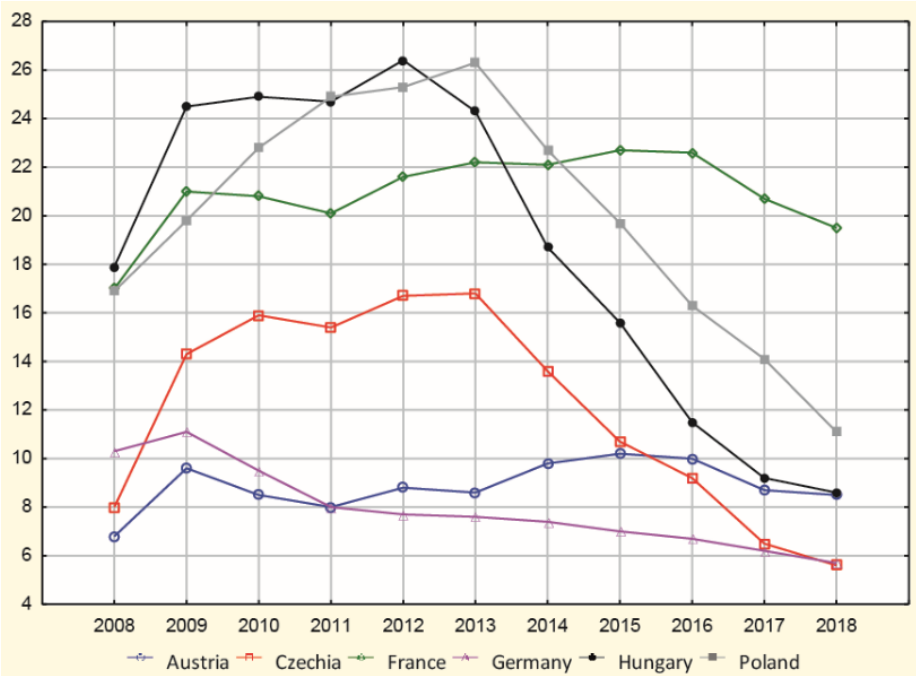

Fig. 3. Total unemployment rate of young people aged 20-24 in the selected European Union countries [in \%]

Source: own elaboration based on (Eurostat (a), n.d.).

\section{Research methodology}

Cluster analysis aims to examine data about multidimensional objects (units or variables) in order to divide the set of these objects into groups (clusters) that exhibit distinctiveness (Maxwell, 1997). The idea of the analysis is to find homogeneous subsets in a heterogeneous set of objects, and thus from a given set of data one extracts a group of objects that are similar to each other, i.e. more similar to the objects making up the group than to the objects outside the group (Balicki, 2013).

This study denoted the set of $\mathrm{n}$ objects by the set $\Omega=\left\{O_{1}, O_{2}, \ldots, O_{n}\right\}$, characterized by $p$ features whose values are contained in the form of matrix $\mathrm{X}$. These objects should be divided into groups (clusters): $C_{1}, C_{2}, \ldots, C_{k}$. The two main application areas of cluster analysis are (Maxwell, 1997):

1. The detection of homogeneous groups of objects for the cognitive and practical purposes, which may involve cluster analysis, identification of objects not belonging to the set of so-called outliers [!].

2. The use of groups in further comparative studies.to assess the dimensionality of a complex phenomenon and to establish diagnostic variables that reflect the most salient properties of objects among a set of variables. 
Cluster analysis includes several different classification algorithms. These algorithms are used to group objects into sets using a similarity or distance measure. The result of this type of research is usually a hierarchical tree, also called a dendrogram, showing the relations between the selected variables on the basis of the adopted criteria. There are several methods for grouping multidimensional objects, among them by (Balicki, 2013; Maxwell, 1997; Trzpiot, 2015):

1. Agglomerative clustering is a hierarchical clustering method in which each element (variable) of a set $\Omega$ is initially treated as a separate one-element group. The first combination creates a group of the two most similar elements, and then combines objects into existing clusters, or combines clusters on the basis of the shortest distance or the highest probability. The distances then need to be recalculated so that they can merge the two closest clusters. When finished, the result is a dendrogram. This method creates an ascending sequence of partitions $P_{1}<P_{2}<$ $\cdots<P_{u}=P_{\Omega}$, where $P_{1}$ is a partition consisting of single-element clusters (individual objects), while $P_{\Omega}$ is equivalent to an undivided (complete) set of objects $\Omega$. Among the agglomeration methods, one can distinguish Ward's method, which uses the variance analysis approach to estimate the distance between clusters, aiming to minimise the sum of squares of the deviations of any two clusters that can be formed at any stage of agglomeration (Ward, 1936).

2. $K$-means clustering relies on the classical $k$-means algorithm where, given a fixed number of $\mathrm{k}$ clusters, one assigns observations to clusters so that the means in the clusters (for all variables in the set) are as different from each other as possible (Hartigan \& Wong, 1978).

\section{Research results}

In accordance with the existing scientific output in the field of quantitative methods, the set of variables characterising the labour markets of selected EU countries, constituting an economic aggregate, is assessed according to statistical criteria (Maxwell, 1997; Panek, 2009; Strahl, 1998). As a result of the verification of the examined variables, 17 macroeconomic and microeconomic variables were included in the study (Trzpiot, 2015):

- $X_{1}$ - youth employment rate;

- $X_{2}$ - young temporary employees as a percentage of the total number of employees;

- $\quad X_{3}$ - part-time employment as a percentage of the total employment for young people;

- $X_{4}$ - involuntary part-time employment as a percentage of the total part-time employment for young people;

- $X_{5}$ - youth unemployment rate; 
- $X_{6}$ - inactive population (inactivity) as a percentage of the total population of young people (is not part of the labour force, meaning is neither employed nor unemployed);

- $X_{7}$ - activity rate of young people (also called labour force, is the population employed or unemployed);

- $X_{8}$-young people by educational attainment level 0-2 (main indicators);

- $X_{9}$-young people by educational attainment level 3-4 (main indicators);

- $X_{10}$ - young people by educational attainment level 5-8 (main indicators);

- $X_{11}$ - young people neither in employment nor in education and training (NEET rates);

- $X_{12}$ - young people neither in employment nor in education and training by labour status - employed;

- $X_{13}$ - young people neither in employment nor in education and training by labour status - not employed;

- $X_{14}$ - people living in households with very low work intensity (population aged 0 to 59) (defined as the number of persons living in a household where the members of working age worked less than $20 \%$ of their total potential during the previous 12 months;

- $X_{15}$ - severe material deprivation rate (an indicator in EU-SILC that expresses the inability to afford some items considered by most people to be desirable or even necessary to lead their life at an adequate standard. The indicator distinguishes between individuals who cannot afford a certain good or service, and those who do not have this good or service for another reason, e.g. because they do not want or do not need it;

- $X_{16}$ - people at risk of poverty or social exclusion (the share of people with an equivalised disposable income (after social transfer) below the at-risk-of-poverty threshold, which is set at $60 \%$ of the national median equivalised disposable income after social transfers. This indicator does not measure wealth or poverty, but low income in comparison to other residents in that country, which does not necessarily imply a low standard of living;

- $X_{17}$ - share of young adults aged 18-34 living with their parents.

In order to obtain unification of the variables, standardisation of variables was used, i.e. standardization of diagnostic characteristics was carried out, performed separately for 2008 and then for 2018. The data thus prepared allowed for proceeding with the studies. First, studies were conducted for 2008, then for 2018, which allowed to see changes in the labour market among young people aged 20-24 in the last decade.

\subsection{Results of analysis for 2008}

The assessment of the distance between the concentrations was based on a line chart showing the Euclidean distance between the concentrations of selected EU countries 
when they were combined (Figure 4). In the agglomeration process graph of the variables tested, where a clear flattening is visible, means that the group is distant. This place is then the "best cut-off point" (Ward, 1963).

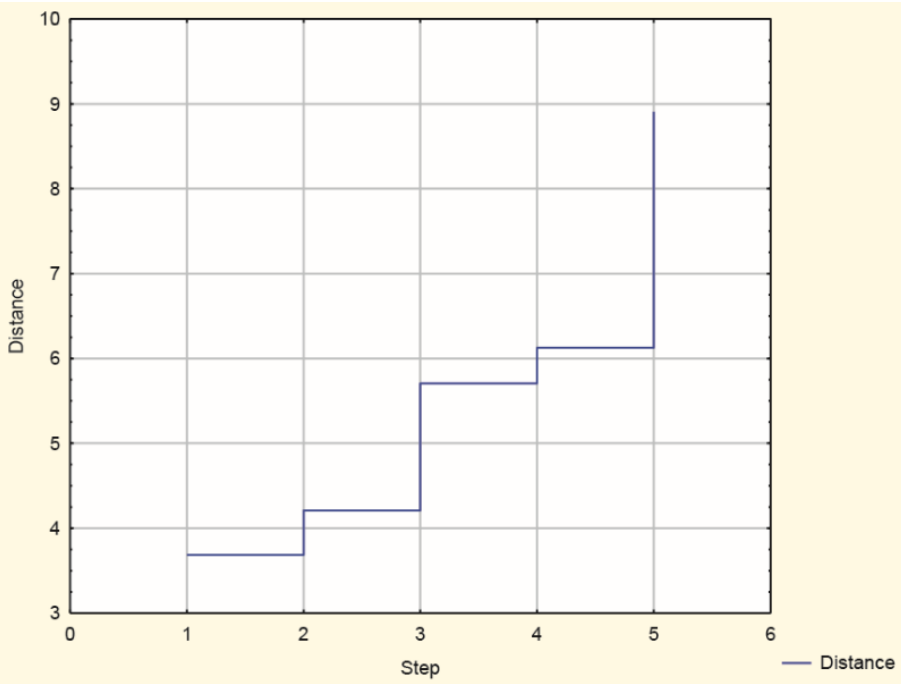

Fig. 4. The agglomeration process for the labour market situation of young people aged 20-24 in selected EU countries in 2008

Source: own elaboration based on (Eurostat (a), n.d.).

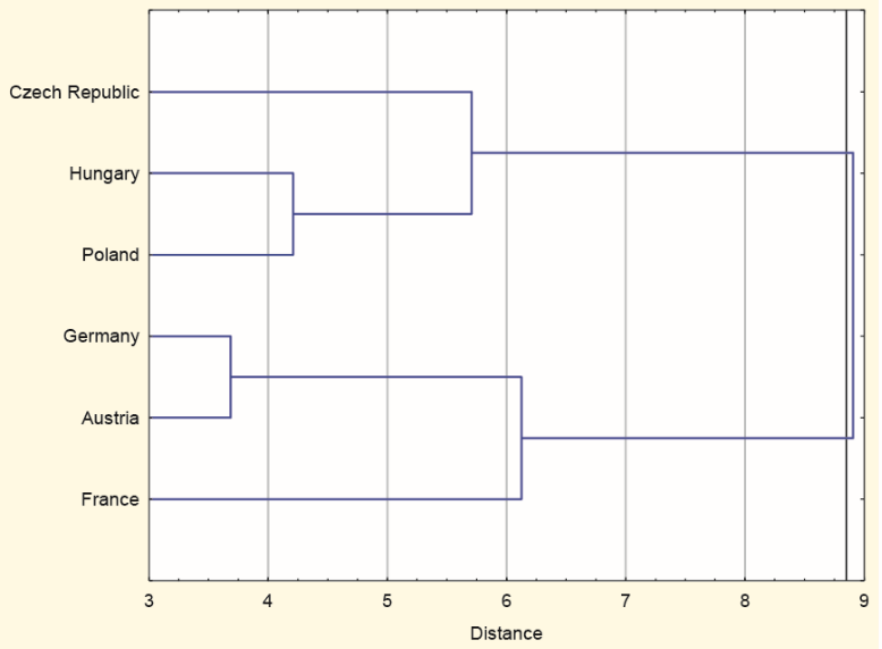

Fig. 5. The labour market situation of young people aged 20-24 in selected EU countries in 2008 Source: own elaboration based on (Eurostat (a), n.d.). 
The analysis of the agglomeration process flow chart indicates that the point where the dendrogram is divided should be placed after 5th step - where the longest vertical line (about 8.85 binding distances) is present.

The use of Ward's hierarchical method (Figure 5) gave rise to the division of the dendrogram (hierarchical tree), allowing for the conclusion that the best solution was to adopt two groups of EU countries in 2008:

- group 1: the Czech Republic, Hungary, Poland;

- group 2: Germany, Austria, France.

To confirm the obtained results of Ward's clustering analysis, $k$-means clustering was applied.

Due to the need to determine the number of clusters in the $k$-means grouping method, the results obtained with the Ward dendrogram division methods were used. As a result, in the Statistica package the number of 2 clusters and 10 iterations was determined. The specified number of iterations proved to be sufficient, which allowed for further analysis. The application of the $k$-means method made it possible to select two clusters of labour markets of young people aged 20-24 in selected EU countries and their distance from the cluster measures.

The analysis by the $k$-means method confirms the previous analysis. In both concentrations ( 1 and 2) there is a variation in the distance between countries and its centre, but in Group 2 it can be seen that one country - Germany - points to a much smaller distance from the centre compared to France and Austria (Table 1), where the first group has similar distances. From an economic point of view, the $k$-means method has a higher value compared to the use of the agglomeration method (Ward dendrogram). This regards a smaller internal differentiation of each of the resulting concentrations of young people's labour market situation in selected EU countries, while at the same time a greater intergroup differentiation. As a result, the composition of individual concentrations does not raise significant doubts.

Table 1. Elements of clusters 1 and 2 for the labour market situation of young people aged 20-24 in selected EU countries in 2008

\begin{tabular}{|c|c|c|c|}
\hline Connect. & $\begin{array}{l}\text { Group element number } 1 \\
\text { and distances from the centre } \\
\text { of proper concentration. } \\
\text { The concentration has three } \\
\text { cases }\end{array}$ & Connect. & $\begin{array}{c}\text { Group element number } 2 \\
\text { and distances from the centre } \\
\text { of proper concentration. } \\
\text { The concentration has three } \\
\text { cases }\end{array}$ \\
\hline & Dist. & & Dist. \\
\hline Czech Republic & 0.7967424 & Germany & 0.4681786 \\
\hline Hungary & 0.7274416 & France & 0.8490456 \\
\hline Poland & 0.5564802 & Austria & 0.7351618 \\
\hline
\end{tabular}

Source: own elaboration based on (Eurostat (a), n.d.). 
The purpose of the $k$-means clustering procedure was to group objects into a user-defined number of clusters. To estimate the accuracy of this classification, the study compare the variability within the clusters (small if the classification is good) with the variability between the clusters (large if the classification is good); this means doing an analysis of variance for each dimension. The observed significance levels ( $p$-value) are not adjusted and therefore should not be interpretable as tests of the hypothesis that the cluster means are equal. Table 2 shows the results of the analysis (ANOVA) of variance for $k$-means clustering, where the means for each cluster in each dimension are examined to estimate how much these clusters differ (Aczel, 2000). Assuming a $p$-value $<0.05$, one can see that variables $X_{1}$, $X_{3}, X_{6}, X_{7}, X_{13}, X_{17}$ guarantee that there are significant differences between the groups formed and they are the criteria for belonging to a given cluster (group). The other studied characteristics contributed most to the intra-group variation in the clusters. The $F$-test in this case is used for descriptive purposes only, since the clusters were chosen to maximize the differences between elements belonging to different clusters.

Table 2. Results of the analysis of variance analysis for the labour market situation of young people aged 20-24 in selected EU countries in 2008

\begin{tabular}{|c|c|c|c|c|c|c|}
\hline \multirow{2}{*}{ Effect } & \multicolumn{7}{|c|}{ Variance analysis } \\
\cline { 2 - 7 } & $(\mathrm{SS})$ & $\mathrm{df}$ & $(\mathrm{MS})$ & $\mathrm{df}$ & $\mathrm{F}$ & $p$-value \\
\hline$X_{1}$ & 3.217 & 1 & 1.783 & 4 & 7.21 & 0.055 \\
\hline$X_{2}$ & 0.084 & 1 & 4.916 & 4 & 0.07 & 0.806 \\
\hline$X_{3}$ & 4.601 & 1 & 0.399 & 4 & 46.12 & 0.002 \\
\hline$X_{4}$ & 1.020 & 1 & 3.980 & 4 & 1.03 & 0.369 \\
\hline$X_{5}$ & 0.502 & 1 & 4.498 & 4 & 0.45 & 0.541 \\
\hline$X_{6}$ & 3.762 & 1 & 1.238 & 4 & 12.15 & 0.025 \\
\hline$X_{7}$ & 3.762 & 1 & 1.238 & 4 & 12.15 & 0.025 \\
\hline$X_{8}$ & 2.403 & 1 & 2.597 & 4 & 3.70 & 0.127 \\
\hline$X_{9}$ & 2.038 & 1 & 2.962 & 4 & 2.75 & 0.172 \\
\hline$X_{10}$ & 0.379 & 1 & 4.621 & 4 & 0.33 & 0.597 \\
\hline$X_{11}$ & 0.366 & 1 & 4.634 & 4 & 0.32 & 0.604 \\
\hline$X_{12}$ & 2.001 & 1 & 2.999 & 4 & 2.67 & 0.178 \\
\hline$X_{13}$ & 3.885 & 1 & 1.115 & 4 & 13.94 & 0.020 \\
\hline$X_{14}$ & 0.233 & 1 & 4.767 & 4 & 0.20 & 0.681 \\
\hline$X_{15}$ & 2.756 & 1 & 2.244 & 4 & 4.91 & 0.091 \\
\hline$X_{16}$ & 0.250 & 1 & 4.750 & 4 & 0.21 & 0.670 \\
\hline$X_{17}$ & 3.519 & 1 & 1.481 & 4 & 9.51 & 0.037 \\
\hline & & & & & & \\
\hline & 1 & 1 & 4 & 4 \\
\hline
\end{tabular}

Source: own elaboration based on (Eurostat (a), n.d.). 


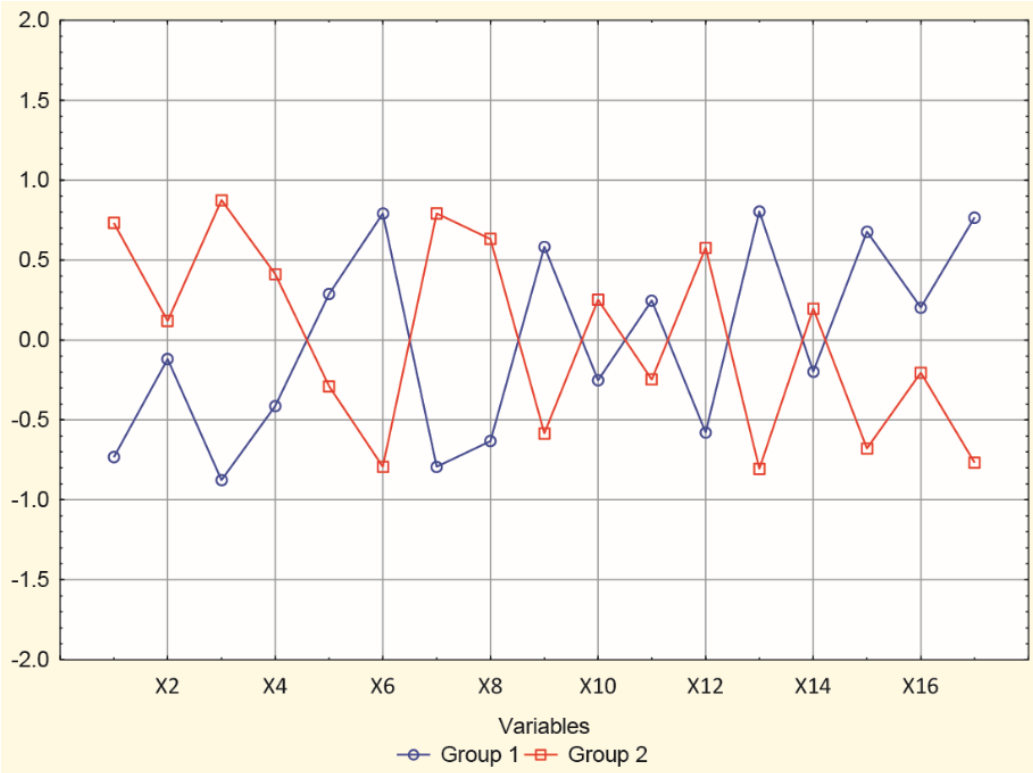

Fig. 6. The $k$-means grouping for the labour market situation of young people aged 20-24 in selected EU countries in 2008

Source: own elaboration based on (Eurostat (a), n.d.).

The final element of the process of verifying the results obtained by the $k$-means grouping is the mean values of both clusters (Figure 6). Based on the graph, one can see that group 1 is characterised by higher values of standardised diagnostic variables for: $X_{5}, X_{6}, X_{9}, X_{11}, X_{13}, X_{15}, X_{16}, X_{17}$, the other characteristics tested are greater for group 2. The estimated average clusters interact with the estimated results of the analysis of intergroup variances and intragroup diagnostic variables. The smallest differences between labour market concentrations occured in the case of $X_{14}$.

\subsection{Results of analysis for 2018}

As with the 2008 analysis, the diagnostic variables were verified with the same set of characteristics tested. In the first step, agglomeration analysis was performed, starting with an assessment of the distance between the concentrations (Figure 7).

The linear graph of the agglomeration flow for the situation of young people in the labour market aged 20-24 illustrates the Euclidean distance between the concentrations of selected EU countries. The point of division of the dendrogram should be placed after 5 steps (the longest vertical line about 9.23 binding distances). 


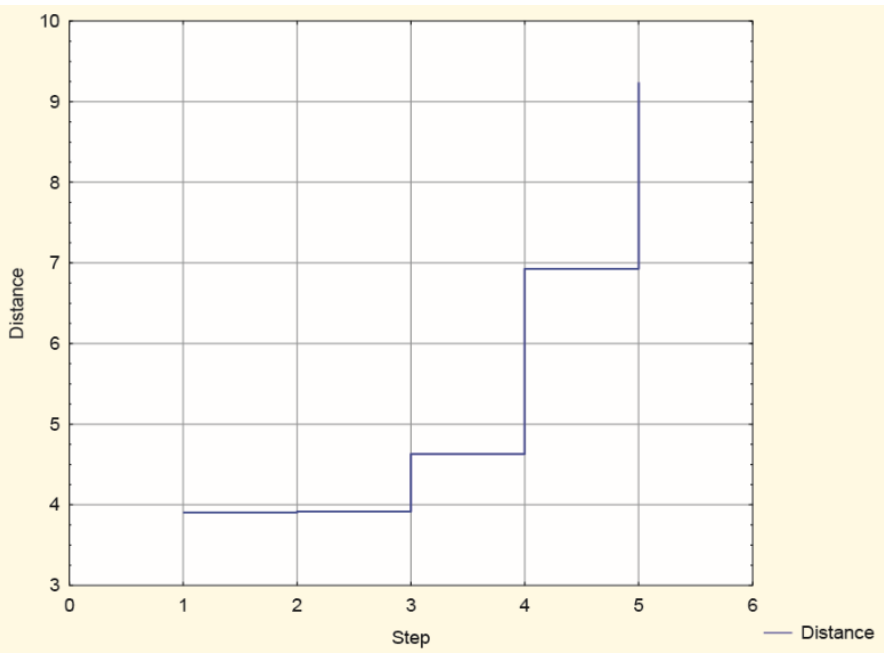

Fig. 7. The agglomeration process for the labour market situation of young people aged 20-24 in selected EU countries in 2018

Source: own elaboration based on (Eurostat (a), n.d.)

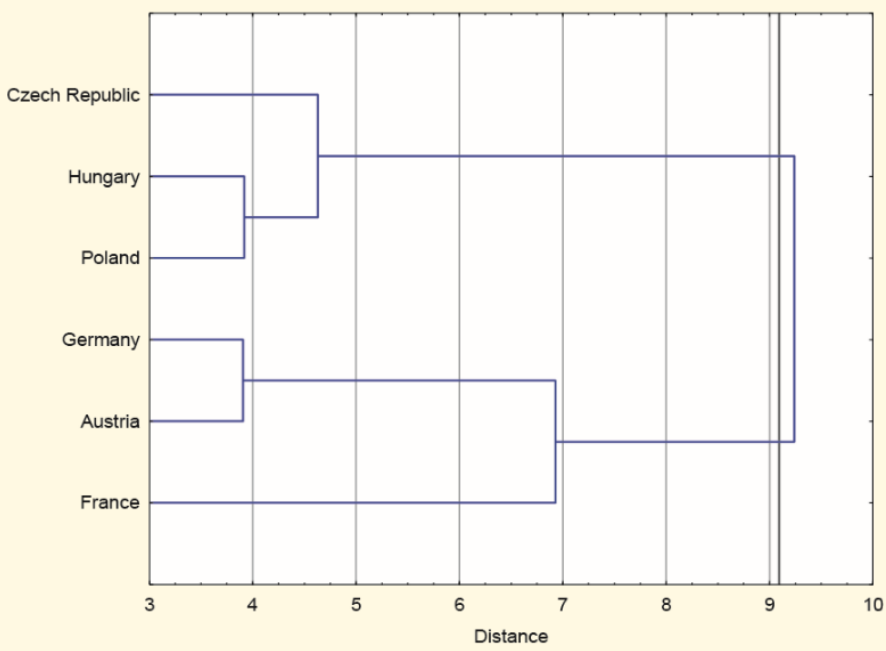

Fig. 8. The dendrogram for the labour market situation of young people aged 20-24 in selected EU countries in 2018

Source: own elaboration based on (Eurostat (a), n.d.).

The results led to the selection of two groups of countries studied (Figure 8):

- group 1: the Czech Republic, Hungary, Poland;

- group 2: Germany, Austria, France. 
As in the case of 2008 , the $k$-means grouping was used to confirm the two clusters obtained.

Table 3. Elements of group 1 and 2 and the distance from the centre of group for the labour market situation of young people aged 20-24 in selected EU countries in 2018

\begin{tabular}{|l|c|l|c|}
\hline \multirow{2}{*}{ Connect. } & $\begin{array}{c}\text { Group element number 1 } \\
\text { and Distances from the centre } \\
\text { of proper concentration the } \\
\text { concentration has 3 cases }\end{array}$ & \multirow{2}{*}{ Connect. } & $\begin{array}{c}\text { Group element number 2 } \\
\text { and distances from the centre } \\
\text { of proper concentration } \\
\text { The concentration has 3 cases }\end{array}$ \\
\cline { 2 - 2 } Czech Republic & dist. & Germany & dist. \\
\hline Hungary & 0.6469944 & France & 0.7401049 \\
\hline Poland & 0.6001438 & Austria & 0.9490479 \\
\hline
\end{tabular}

Source: own elaboration based on (Eurostat (a), n.d.).

The elements of concentration 1 and the distances from the centre of the proper concentration for the labour market situation of young people indicate that the distances of individual countries from its centre are less differentiated in comparison with concentration 2, where these distances are highly differentiated, while the country with the greatest distance is France and the smallest is Austria (Table 3).

Table 4. Results of the analysis of variances for the labour market situation of young people aged 20-24 in selected EU countries in 2018

\begin{tabular}{|c|c|c|c|c|c|c|}
\hline \multirow{2}{*}{ Effect } & \multicolumn{5}{|c|}{ Variance analysis } \\
\cline { 2 - 6 } & $(\mathrm{SS})$ & $\mathrm{df}$ & $(\mathrm{MS})$ & $\mathrm{df}$ & $\mathrm{F}$ & $p$-value \\
\hline$X_{1}$ & 2.500 & 1 & 2.500 & 4 & 4.00 & 0.116 \\
\hline$X_{2}$ & 0.091 & 1 & 4.909 & 4 & 0.07 & 0.799 \\
\hline$X_{3}$ & 4.754 & 1 & 0.246 & 4 & 77.44 & 0.001 \\
\hline$X_{4}$ & 0.870 & 1 & 4.130 & 4 & 0.84 & 0.411 \\
\hline$X_{5}$ & 0.441 & 1 & 4.559 & 4 & 0.39 & 0.568 \\
\hline$X_{6}$ & 3.851 & 1 & 1.149 & 4 & 13.41 & 0.022 \\
\hline$X_{7}$ & 3.851 & 1 & 1.149 & 4 & 13.41 & 0.022 \\
\hline$X_{8}$ & 0.987 & 1 & 4.013 & 4 & 0.98 & 0.377 \\
\hline$X_{9}$ & 4.102 & 1 & 0.898 & 4 & 18.27 & 0.013 \\
\hline$X_{10}$ & 1.932 & 1 & 3.068 & 4 & 2.52 & 0.188 \\
\hline$X_{11}$ & 0.096 & 1 & 4.904 & 4 & 0.08 & 0.793 \\
\hline$X_{12}$ & 3.860 & 1 & 1.140 & 4 & 13.55 & 0.021 \\
\hline$X_{13}$ & 3.261 & 1 & 1.739 & 4 & 7.50 & 0.052 \\
\hline$X_{14}$ & 2.248 & 1 & 2.752 & 4 & 3.27 & 0.145 \\
\hline$X_{15}$ & 0.420 & 1 & 4.580 & 4 & 0.37 & 0.577 \\
\hline$X_{16}$ & 0.274 & 1 & 4.726 & 4 & 0.23 & 0.655 \\
\hline$X_{17}$ & 2.524 & 1 & 2.476 & 4 & 4.08 & 0.114 \\
\hline
\end{tabular}

Source: own elaboration based on (Eurostat (a), n.d.). 
As mentioned before, the $F$-test is only used for descriptive purposes, in order that the selected clusters maximise the differences between the elements belonging to the clusters. Table 4 shows the results of analyses of variance (ANOVA), where for variables $X_{3}, X_{6}, X_{9}, X_{12}, X_{13}, X_{7}, X_{9}, X_{12}, X_{13}$ the $p$-value is below 0.05 (Table 4 ).

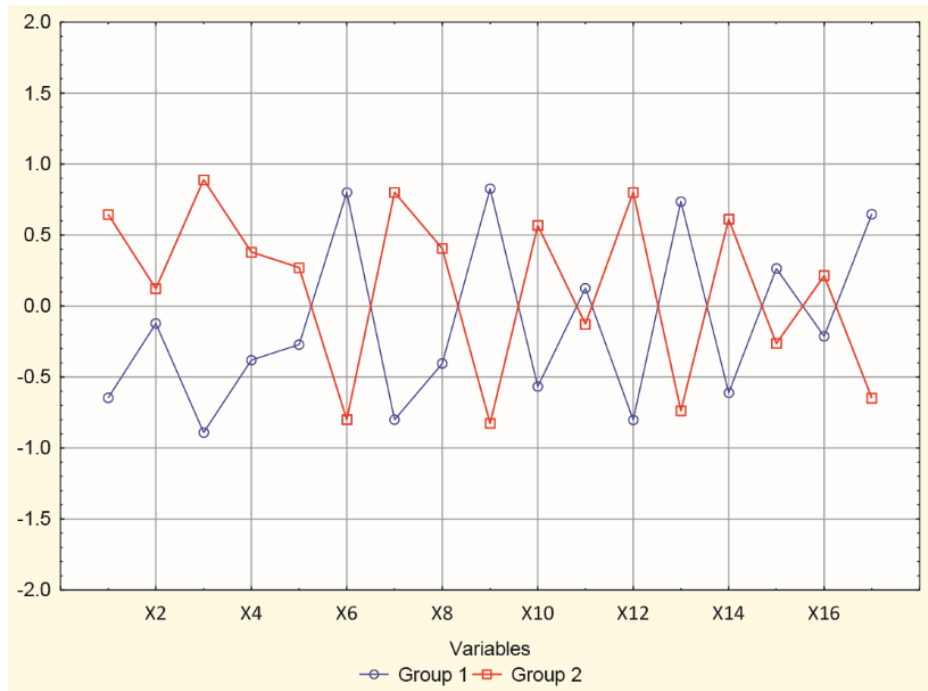

Fig. 9. The $k$-means grouping for the labour market situation of young people aged 20-24 in selected EU countries in 2018

Source: own elaboration based on (Eurostat (a), n.d.).

The final element was the process of verification of the obtained results by grouping the $k$-means of both clusters (Figure 9). Group 1 is characterised by higher values of standardised diagnostic variables for: $X_{6}, X_{9}, X_{11}, X_{13}, X_{15}, X_{17}$, while other examined features are larger for group 2. The estimated mean clusters interact with the estimated results of analyses of intergroup and intragroup diagnostic variables. The smallest differences between the clusters in the labour market occured for variable $X_{11}$.

\section{Discussion}

The labour market is an area of extraordinary dynamism. Young people are one of the social groups in the labour market. This is a group with very great opportunities in terms of personal development, improvement of qualifications and also selfdiscipline. Despite the above-mentioned advantages which are only a narrow range, young people face numerous limitations on the labour market. The problem lies in the requirements of employers for the professional experience of young people, 
which due to them only beginning their career path on the labour market is usually small. Employers are aware that these are persons who have finished secondary school or are studying, however, having a choice between an employee with no experience and an employee with experience who knows how the system of work functions and whose preparation is not be burdened with additional costs, they will choose the second option, which is of course justified. Nevertheless, such an approach raises further problems, so an increase in unemployment is inevitable. This decade has seen unemployment fall in every country except for Austria (unemployment rate up 25\%) and France (up 14.7\%). In other countries, unemployment rates have decreased: in the Czech Republic (30\%), Germany (45\%), Hungary (52\%) and Poland (34\%).

The research procedure identified two groups of countries that had a similar structure of factors influencing the development of the youth labour market in 2008 and 2018 separately. This made it possible to answer the two key research questions posed: "Which EU countries form clusters and what variables determine these clusters?", and "How has the labour market situation of young people changed over the decade?".

The results indicated two clusters formed from the six selected European Union countries. The first cluster consists of the Czech Republic, Hungary and Poland, and the second cluster of Austria, France and Germany. The generated dendrograms show how the clusters are shaped. It allowed us to observe certain structural similarities between the selected countries in terms of the labour market situation of young people aged 20-24. For 2008, in the case of the first cluster it is the Czech Republic, where Hungary and Poland are more similar in terms of the examined characteristics, although the $k$-means method shows that according to the cluster elements and the distance from the centre of the proper cluster, whereas the Czech Republic and Hungary have similar values ( 0.79 and 0.72 respectively), while Poland (0.55). In the case of the second cluster, one can see that France is the country that stands apart from Germany and Austria, while according to the distance from the centre of the proper cluster, France and Austria have similar values $(0.84$ and 0.73 , respectively), while for Germany it is lower (0.46). In 2018, in the clusters according to the dendrograms, the same outliers can be observed against the cluster. Differences that can be observed are the convergence of the values of the distance from the centre of the respective cluster for the $k$-means method, where in cluster one the values are between 0.54 and 0.64 , suggesting that the examined factors were at a similar level during the decade. In the case of the second cluster the values for Germany, France and Austria are 0.74, 0.94 and 0.59, respectively. Thus France in comparison to the other two countries is the most distant country from Austria, but its value is similar to Germany. The differences result from the economic structures, each of the EU countries shows certain differentiation, for example in the structure of education and development in the labour market; the population of a given country should also be taken into account. 
The research results obtained by means of cluster analysis using hierarchical and non-hierarchical methods allowed to draw the following conclusions:

- The main criterion for clustering similarities in the labour market of young people in selected countries of the European Union in 2008 and 2018 are four macroeconomic and demographic variables, which were selected on the basis of $k$-means clustering verification. These are: employment rate of young people $\left(X_{1}\right)$, part-time employment as a percentage of total employment of young people $\left(X_{3}\right)$, activity rate of young people $\left(X_{7}\right)$, percentage of young adults aged 18-34 living with at least one parent $\left(X_{17}\right)$. In relation to the research hypothesis, the analysis revealed a narrow range of variables significantly influencing the criterion of group membership. However, the analysis provides an insight into the situation of young people who face difficulties when they enter the labour market. The results of the analysis also provide a perspective for expanding research that will focus in detail on the problem at hand.

- The variables with the least impact on the clustering of selected EU countries in 2008 and 2018 are: the share of young people in education who are not in employment, education or training (NEET indicator) variable $X_{11}$.

As a result of the $k$-means clustering method in 2008 and 2018 group 2, i.e. Austria, France and Germany, have higher average values of the various diagnostic characteristics studied. The $k$-means clustering method combines the studied variables on the labour market situation of young people aged 20-24 into homogeneous clusters in a way that is justified from the point of view of economic diversification. In contrast, less accurate results were obtained using agglomeration methods (Ward's method).

The research has raised the issue of the situation of young people on the labour market, who are not in an interesting situation. One of the factors influencing the grouping is part-time employment as a percentage of total employment of young people, obviously regarding casual jobs which are mainly aimed at providing just an additional income for young people who also take up such jobs due to the lack of other opportunities resulting from the mismatch between the labour market and people without professional qualifications and thus without experience. Among the factors influencing the grouping is the variable percentage of young adults aged 18-34 living with at least one parent resulting from social integration; this is often a factor due to which young people are not taken seriously, which at the same time affects the self-esteem and well-being of the young person discouraging them from looking for work. Therefore, it is necessary to undertake broader systemic measures towards them. The basis for this are the changes in the current labour market legislation made in 2014. They fundamentally modify the existing passive solutions relating to young people. Young people are eager to work, which is indicated by the significant impact of the youth activity rate and the employment rate.

Answering the question "How has the labour market situation of young people changed over the decade" first of all, one can observe an increase in employment of 
young people aged 20-24, and thus decreased youth unemployment, with the biggest drop in Hungary (in 10 years, by as much as $45 \%$, followed by Germany $-45 \%$, and Poland $-34 \%$ ). The only country with a $15 \%$ increase in unemployment was France. This may be due to the large increase in the level of education in the countries concerned, where in some countries it is an eightfold increase (Austria). One can also see a big influence on unemployment and thus clustering of the NEET rate, which decreased in most countries. The participation of young people in education has a big influence on their future, because these are additional assets for the employer. Regarding the social inclusion of young people, one can observe a large decrease in most countries, which suggests that the standard of living is rising associated with an increase in employment.

It should be noted that the examined factors have a particular impact on the employment of young people. Social exclusion, the lack of access to education, and the level of unemployment bring negative consequences related to unused capital, and therefore human potential, and also related to unwillingness for self-realisation, self-development, as well as social withdrawal. The restriction of access to education resulting from various external and internal factors, such as place of residence, and lack of resources, translates directly into an organic increase of qualifications or their expansion. All the negative factors translate into the everyday life of young people, which are reflected in their social status, and their psychological state. Thus, social exclusion can lead not only to antisocial attitudes of young people, discouraged towards any activities, but can also increase the migration of young people. The study showed that this topic is extremely important and research should be deepened to include other factors influencing youth unemployment. It should be borne in mind that youth unemployment has numerous social and economic consequences. Unused potential translates into unused available human resources. Therefore, it is important to pay special attention to the behaviour of this social group in future research.

\section{Conclusion}

In conclusion, the cluster analysis allowed the EU selected countries to be grouped together comparing the minimum differences between selected factors related to the labour market of young people aged 20-24 in 2008 and 2018 separately. Two grouping methods were used for the analysis: the agglomeration method (using the Ward method) and the $k$-means method. In both compared years, i.e. 2008 and 2018, the groups of the selected countries (clusters) developed similarly, as also seen in the assessment of labour market developments in socio-demographic terms and in the assessment of youth employment and unemployment.

The research examined two clusters, for which the determining factors are the employment rate, part-time employment, the percentage of people aged 18-34 living with at least one parent, and the activity rate of young people aged 20-24. These variables relate directly to the situation of young people on the labour market. Young 
people, despite their activity on the labour market and high involvement in their own development, face a kind of 'barrier' created on the labour market, which makes them decide to work part-time in order to gain experience. However, this work is often not related to their profession or does not correspond to their competences. As mentioned before, one can see an increase in the share of young people in education who are working, which shows that they want to develop themselves while at the same time gaining experience and improving their personal social integration.

The study only focused on some aspects concerning the specificity of the contemporary labour market and thus attempts to assess the situation of young people aged 20-24 on the labour market in selected EU countries. It is extremely important to undertake further research in the field of unemployment of young people who enter the labour market in order to draw attention to such an important issue as the limitations on the labour market of young people without adequate competences and professional experience, who at the same time constitute a group of employees who quickly adapt to a given environment and are eager to work and learn which is shown by the activity rate of young people. When considering their future, young people must be extremely active from the moment of education (secondary school, university as a student), and precisely from reaching working age and entering the labour market up to reaching the retirement age. Functioning on the market is not easy for young people, but also for other age groups, therefore it is important to undertake an active labour market policy that allows for improved employment and personal development.

\section{References}

Aczel, A. D. (2000). Statystyka w zarzadzaniu. Warszawa: Wydawnictwo Naukowe PWN.

Aczel, A. D., \& Sounderpandian, J. (2017). Statystyka w zarządzaniu. Warszawa: Wydawnictwo Naukowe PWN.

Balicki, A. (2013). Statystyczna analiza wielowymiarowa i jej zastosowania społeczno-ekonomiczne. Gdańsk: Wydawnictwo Uniwersytetu Gdańskiego.

Bauman, Z., Bauman, I., Kociatkiewicz, J., \& Kostera, M. (2017). Zarzadzanie w plynnej rzeczywistości Wydawnictwo Bęc Zmiana. Retrieved from https://www.rsearchgate.net/publication/ 337916759_Zarzadzanie_w_plynnej_nowoczesnosci

Cormack, R. M. (1971). Journal of the Royal Statistical Society. Series A (General). A Review of Classification, 134(3), 321-367. https://doi.org/10.2307/2344237

Dagnelie, P. (1975). Analyse statistique ŕ plusieres variables. Gambloux: Les Presse Agronomique. https://doi.org/10.2307/2344898

Drela, K. (2017). Zmiany demograficzne a rynek pracy w Polsce. Prace Naukowe Uniwersytetu Ekonomicznego we Wroctawiu. Ekonomia, (489), 78-85. Retrieved from https://dbc.wroc.pl/ Content/39351/PDF/Drela_Zmiany_Demograficzne_a_Rynek_Pracy_w_Polsce_2017.pdf

Eurostat (a). (n.d.). Metadata: Population by educational attainment level. Retrieved from https://ec.europa.eu/eurostat/data/metadata

Eurostat (b). (n.d.). Metadata: Population (national level), reference metadata in Euro SDMX metadata structure (ESMS). Retrieved from https://ec.europa.eu/eurostat/cache/metadata/en/ demo_pop_esms.htm 
Feifs, T. (2011). Dobre praktyki zarządzania kapitałem ludzkim - perspektywa europejska. In M. Juchnowicz (Eds.), Najlepsze praktyki w zarzadzaniu kapitałem ludzkim. Metodyka badania, opisy przypadków (pp. 87-90). Warszawa: Oficyna Wydawnicza SGH.

Frątczak, E. (Ed.). (2009). Wielowymiarowa analiza statystyczna. Teoria - przykłady zastosowań z systemem SAS. Warszawa: Szkoła Główna Handlowa w Warszawie.

Friedman, G. (2010). The next 100 years - a forecast for the 21 st Century. Allison \& Busby.

Hartigan, J. A., \& Wong, M. A. (1978). Algorithm 136. A k-means clustering algorithm. Applied Statistics, 28-100. https://doi.org/10.2307/2346830

Jadamus-Hacura, M., \& Melich-Iwanek, K. (2015). Elastyczność współczesnych rynków pracy. Studia Ekonomiczne. Zeszyty Naukowe Uniwersytetu Ekonomicznego w Katowicach, (220), 55-60. Retrieved from https://www.sbc.org.pl/dlibra/publication/188732/edition/177577/content

Jamka, B. (2009). Zarządzanie wiekiem 50+ jako wyzwanie współczesnych przedsiębiorstw. In B. Jamka, S. Konarski (red.), Zarządzanie zasobami ludzkimi a zdolności adaptacyjne przedsiębiorstw. Trudne obszary. Warszawa: Oficyna Wydawnicza SGH.

Janiszewska, A., \& Dmochowska-Dudek, K. (2017). Przestrzenne zróżnicowanie starzenia się ludności w Łodzi. Space - Society - Economy, (20), 9-22.

Kompetencje kluczowe w uczeniu się przez całe życie. (2007). Europejskie Ramy Odniesienia. Luxembourg: Urząd Oficjalnych Publikacji Wspólnot Europejskich. Retrieved from http://waloryzacja.llp.org.pl/sites/waloryzacja.llp.org.pl/files/keycomp_pl.pdf

Krause, E. (2016). Zjawisko NEET, czyli o młodzieży trzy razy nic. Problemy Profesjologii, (2), 67-81. Retrieved from http://yadda.icm.edu.pl/yadda/element/bwmeta1.element.desklight-6a54d 04e-7e19-4821-8292-f05f23dadc7f

Laczó, F., \& Gabrijelčič, L. L. (2020). The legacy of division. East and West after 1989. Central European University Press. https://doi.org/10.7829/j.ctv176kthp

Lewandowski, P., \& Rutkowski, J. (2017). Starzenie się ludności, rynek pracy i finanse publiczne $w$ Polsce. Warszawa: Wydawnictwo Przedstawicielstwo Komisji Europejskiej w Polsce. Retrieved from https://op.europa.eu/en/publication-detail/-/publication/1f2adf3c-055d-11e7-8a 35-01 aa75ed71a1/language-pl

Lichtarski, J. (Ed.). (1999). Podstawy nauki o przedsiębiorstwie. Wrocław: Wydawnictwo Akademii im. Oskara Langego we Wrocławiu.

MacQueen, J. B. (1967). Some methods for classification and analysis of multivariate observations. (Proceedings of 5th Berkeley Symposium on Mathematical Statistics and Probability, 1, pp. 281 -297). University of California Press. MR 0214227. Zbl 0214.46201. Retrieved April 7, 2009 from http://www.cs.cmu.edu/ bhiksha/courses/mlsp.fall2010/class14/macqueen.pdf

Mardia, K. V., Kent, J. T., \& Bibby, J. M. (1979). Multivariate analysis. London: Academic Press. https://doi.org/10.1002/bimj.4710240520

Marek, T. (1989). Analiza skupień w badaniach empirycznych. Metody SAHN. Warszawa: PWN.

Maxwell, A. E. (1997). Multivariate analysis in behavioural research. London: Chapman \& Hall.

Mikulec, A. (2013). Kryterium Mojeny i Wisharta w analizie skupień - przypadek skupień o różnych macierzach kowariancji. Prace Naukowe Uniwersytetu Ekonomicznego we Wrocławiu, (278). Retrivered form https://www.dbc.wroc.pl/dlibra/publication/27250/edition/24641 ?language=pl

Milewski, R. (2017). Elementarne zagadnienia ekonomii. Warszawa: Wydawnictwo Naukowe PWN.

Nojszewska, E. (1995). Podstawy ekonomii. In Z. Sadowski, T. Wach, Encyklopedia pracy. Warszawa.

Osiecka-Chojnacka, J. (2007). Szkolnictwo zawodowe wobec problemów rynku pracy. Biuro Analiz Sejmowych, INFOS, (16), 2-4. Retrieved from http://orka.sejm.gov.pl/WydBAS.nsf/0/ 13B16A06B8557C14C12572F200384FC9/ \$file/infos_016.pdf

Panek, T. (2009). Statystyczne metody wielowymiarowej analizy porównawczej. Warszawa: Wydawnictwo Szkoły Głównej Handlowej. Retrieved from https:/www.researchgate.net/ publication/267241683_Statystyczne_metody_wielowymiarowej_analizy_porownawczej_Teoria i_zastosowania 
Rachwał, T. (2005). Kształtowanie postaw u uczniów na lekcjach przedsiębiorczości. Przedsiębiorczość - Edukacja, (1), 137-144. Retrieved from https://p-e.up.krakow.pl/article/ download/729/609

Rybicka, K. (2014). Sytuacja młodzieży na polskim rynku pracy. Zeszyty Naukowe Uniwersytetu Szczecińskiego. Studia i Prace Wydziału Nauk Ekonomicznych i Zarzadzania, 37(2), 105-116. Retrieved from http://yadda.icm.edu.pl/yadda/element/bwmeta1.element.ekon-element-000 171363335

Saczyńska-Sokół, S., \& Łojko, M. (2016). Sytuacja młodzieży NEET na rynku pracy. Zeszyty Naukowe Uniwersytetu Przyrodniczo-Humanistycznego $w$ Siedlcach. Administracja $i$ Zarzadzanie, (108), 97-106. Retrieved from https://repozytorium.uph.edu.pl/bitstream/handle/11331/ 600/Saczynska-Sokol_Lojko_Sytuacja_mlodziezy_NEET.pdf?sequence=1

Stasiak, J. (2011). System edukacji wobec wyzwań rynku pracy w Polsce. Folia Oeconomica, (248), 352-360. Retrieved from http://yadda.icm.edu.pl/yadda/element/bwmeta1.element.ekon-element000171190881

StatSoft. (n.d.). Internetowy podręcznik statystyki: analiza skupień. Retrieved from https://www.statsoft.pl/textbook/stathome.html

Strahl, D. (Ed.). (1998). Taksonomia struktur $w$ badaniach regionalnych. Wrocław: Wydawnictwo Akademii Ekonomicznej we Wrocławiu.

Szcześniak, M. G. (2011). Pokolenie ,ani-ani”: o młodzieży, która się nie uczy, nie pracuje i nie dba o samokształcenie. Psychologia Społeczna, 3(18), 241-251. Retrieved from https://www.researchgate.net/publication/276027016_Pokolenie_an-ani_o_mlodziezy_ktora_ sie_nie_uczy_nie_pracuje_i_nie_dba_o_samoksztalcenie

Trzpiot, G. (Ed.). (2015). Modelowanie wielowymiarowych struktur danych $i$ analiza ryzyka. Katowice: Wydawnictwo Uniwersytetu Ekonomicznego w Katowicach. Retrieved from https://www.ue.katowice.pl/jednostki/wydawnictwo/oferta-wydawnicza/monografie/trzpiot-gred-modelowanie-wielowymiarowych-struktur-danych-i-analiza-ryzyka-2015.html

Ustawa z dnia 20 kwietnia 2004 r. o promocji zatrudnienia i instytucjach rynku pracy (tekst jedn. Dz. U. z 2013 r., poz. 674 ze zm.). Retrieved from http://isap.sejm.gov.pl/isap.nsf/dowload xsp/ WDU20040991001/T/D20041001L.pdf

Ward, J. H. (1963). Hierarchical grouping to optimize an objective function. Journal of the American Statistical Association, 58-236. https://doi.org/10.2307/2282967

\section{OCENA SYTUACJI NA RYNKU PRACY OSÓB MLODYCH W WYBRANYCH KRAJACH UNII EUROPEJSKIEJ - PODEJŚCIE TAKSONOMICZNE}

Streszczenie: Celem artykułu jest klasyfikacja obiektów, jakimi są rynki pracy ludzi młodych w wybranych krajach UE, służąca stworzeniu względnie jednorodnych grup na podstawie zestawu rozpatrywanych zmiennych. Pozwoliła ona na zbadanie podobieństw wybranych państw członkowskich oraz porównanie lat 2008 i 2018. W analizie posłużono się danymi EUROSTAT (17 zmiennych makroekonomicznych i demograficznych) dla wybranych krajów Unii Europejskiej. W badaniu wykorzystano metody hierarchiczne do aglomeracji obiektów za pomocą dendrogramu, co pozwoliło na zobrazowanie powiązań między krajami z wykorzystaniem metody Warda dla odległości euklidesowych. Zastosowano też niehierarchiczną metodę $k$-średnich do badania alokacji obiektów i oceny istotności badania przez minimalizację zmienności w obrębie powstałych skupień, a tym samym maksymalizację zmienności między skupieniami. Uzyskane wyniki stanowią podstawę do doskonalenia miar sytuacji młodzieży na rynku pracy przez wskazanie czynników istotnie wpływających na poziom zatrudnienia i bezrobocia osób młodych. Opracowanie stanowi asumpt do przyszłych badań nad sytuacją na rynku pracy w krajach członkowskich.

Słowa kluczowe: rynek pracy, analiza skupień, podejście taksonomiczne, kraje Unii Europejskiej. 